\title{
PENGARUH KEPUTUSAN INVESTASI DAN KEBIJAKAN HUTANG TERHADAP NILAI PERUSAHAAN (Perusahaan Telekomunikasi Yang Terdaftar Di BEI 2013-2017)
}

\author{
Siti Umaroh \\ Email : sitiumarohhh@gmail.com
}

Prodi Manajemen, Sekolah Tinggi Ilmu Ekonomi (STIE)Muhammadiyah Palopo

\begin{abstract}
Abstrak
Penelitian ini bertujuan menguji pengaruh variabel keputusan investasi dan kebijakan hutang terhadap nilai perusahaan pada perusahaan telekomunikasi periode tahun 2013-2017 yang terdaftar di Bursa Efek Indonesia. Sampel yang digunakan adalah purposive sampling dengan tipe judgement sampling dimana pemilihan sampel dengan mendasarkan pada kriteria tertentu. Sebanyak 5 (lima) laporan tahunan dari 5 (lima) perusahaan telekomunikasi yang menerbitkan laporan yang diperoleh melalui situs resmi Bursa Efek Indonesia (www.idx.co.id). Pengujian menggunakan teknik analisis regresi linier berganda dengan alat bantu SPSS (Statistical Package for Social Sciences), dengan variabel keputusan investasi menggunakan ukuran price earnings ratio (PER) yang lebih merujuk kepada signaling theory dan/atau agency theory dan variabel kebijakan hutang menggunakan ukuran debt to equity ratio (DER).Jenis penelitian ini adalah penelitian kuantitatif, selanjutnya metode pengumpulan data yang digunakan adalah libraryresearch, field research dan internet research. Teknik pengolahan dan analisis data dilakukan melalui uji analisis deskriptif, asumsi klasik, analisis regresi linear berganda, koefisien determinasi $\left(\mathrm{R}^{2}\right)$,dan uji t. Hasil penelitian menunjukkan bahwa variabel keputusan investasi berpengaruh positif dan signifikan terhadap nilai perusahaan, Perusahaan yang memiliki PER positif akan direspon positif oleh investordengan membeli saham sehingga menaikkan nilai perusahaan, sedangkan variabel kebijakan hutang tidak berpengaruh terhadap nilai perusahaan, hal tersebut karena investor cenderung melihat kepada pihak manajemen dalam pengelolaan dana untuk mencapai nilai tambah bagi nilai perusahaan.
\end{abstract}

Kata Kunci: Nilai Perusahaan, Signaling Theory, Keputusan Investais, dan Kebijakan Hutang

\section{PENDAHULUAN}

Perkembangan yang dinamis dan kemajuan perusahaan telekomunikasi yang cukup signifikan tidak lepas dari peran aktif masyarakat dalam penggunan media komunikasi, dikarena perusahan selalu ingin memberikan yang terbaik kepada konsumen untuk dapat mempertahankan eksistensi perusahaan. Di Indonesia, kehadiran industri telekomunikasi sangat berperan untuk keberlangsungan kelancaran kegiatan ekonomi. Berdasarkan kebutuhan konsumen yang ada, menjadi peluang bagi perusahaan operator telepon seluler untuk memenuhi kebutuhan masyarakat, maka saat ini semakin banyak bermunculan merk operator seluler baik GSM (Global System for Mobile Communications), maupun CDMA (Code Division Multiple
Accsess) yang tersedia di pasaran sehingga membuat persaingan antar perusahaan sejenis semakin ketat.

Tabel 1.1

Klasifikasi Produk dan Jaringan Perusahaan Telekomunikasi yang Terdaftar di Bursa Efek Indonesia

\begin{tabular}{|c|l|l|l|}
\hline No & Perusahaan & Produk & Jaringan \\
\hline 1. & $\begin{array}{l}\text { Bakrie } \\
\text { Telecom }\end{array}$ & Esia & CDMA \\
\hline 2. & IndosatTbk. & IM3 & GSM, CDMA \\
\hline 3. & $\begin{array}{l}\text { Smatrfren } \\
\text { Telecom. }\end{array}$ & $\begin{array}{l}\text { Smartfren, } \\
\text { Hepi }\end{array}$ & CDMA \\
\hline 4. & $\begin{array}{l}\text { Telekomunika } \\
\text { si Indonesia }\end{array}$ & AS, Simpati, & GSM \\
\hline
\end{tabular}



5. XL Axiat
XL
GSM

Berdasarkan data historis BEI, saham perusahaan telekomunikasi selalu bergerak aktif.Berkembangnya penggunaan teknologi yang semakin pesat mengakibatkan berubahnya struktur pasar dari pasar monopolistik menjadi pasar yang kompetitif.Salah satu indikasi dari pasar kompetitif, misalnya dengan maraknya perang aktif antar operator atau service provider.Tarif yang ditawarkan antar operator sangat menarik konsumen, dari keputusan pemilihan konsumen inilah terjadi persaingan pasar yang cukup aktif.

\section{METODE PENELITIAN}

Tempat dilakukannya penelitian ini yaitu pada Bursa Efek Indonesia melalui situs resmi yang diakses secara online di http://www.idx.co.id. Penelitian dilakukan pada 2013-2017

Data yang digunakan dalam penelitian ini adalah berupa rasio-rasio laporan keuangan dari laporan keuangan yang terbit setiap akhir periode laporan keuangan pada perusahaantelekomunikasiyang terdaftardi bursa efek Indonesia untuk periode2013-2017. http://www.idx.co.id. Dalam hal ini, peneliti tidak hadir langsung untuk melakukan penelitian, peneliti hanya mengumpulkan data melalui data yang telah tersedia atau dengan kata lain peneliti menggunakan metode dokumentasi secara online. Pengelolaan dan analisis data dalam penelitian ini menggunakan teknik statistik deskriptif dan analisis regresi berganda dimana dapat dirumuskan dalam persamaan sebagai berikut :

$$
\mathbf{Y}=\alpha+\boldsymbol{\beta}_{1} \mathbf{X}_{1}+\boldsymbol{\beta}_{2} \mathbf{X}_{2}+\mathbf{e}
$$

\section{Keterangan:}

$$
\begin{array}{ll}
\mathrm{Y} & =\text { Nilai Perusahaan } \\
\alpha & =\text { Konstanta } \\
\mathrm{X}_{1} & =\text { Keputusan Investasi } \\
\mathrm{X}_{2} & =\text { Kebijakan Hutang } \\
\mathrm{e} & =\text { Error atau penyimpangan yang mungkin }
\end{array}
$$
terjadi $b_{1}, b_{2}=$ Koefisien regresi dari variabel $X_{1}$ dan $\mathrm{X}_{2}$

\section{HASIL DAN PEMBAHASAN}

\section{Uji Parsial (Uji T)}

Uji t dimaksudkan untuk mengetahui

\begin{tabular}{|c|c|c|c|c|c|}
\hline \multirow[b]{2}{*}{ Model } & \multicolumn{2}{|c|}{ Unstandardized Coefficients } & $\begin{array}{l}\text { Standardized } \\
\text { Coefficients }\end{array}$ & \multirow[b]{2}{*}{$\mathrm{t}$} & \multirow[b]{2}{*}{ Sig. } \\
\hline & $\mathrm{B}$ & Std. Error & Beta & & \\
\hline $1 \quad$ (Constant) & 214.490 & 34.849 & & 6.155 & .025 \\
\hline Keputusan Investasi (X1) & 1.383 & .398 & .679 & 3.475 & .047 \\
\hline Kebijakan Hutang (X2) & -.418 & .218 & -.375 & -1.918 & 19 \\
\hline
\end{tabular}
apakah terdapat pengaruh masing-masing variabel independen terhadap nilai perusahaan pada perusahaan telekomunikasi.

Hasil Uji t

Coefficients $^{\mathrm{a}}$

a. Dependent Variable: Nilai Perusahaan (Y)

1. Pengaruh Variabel keputusan investasi terhadap nilai perusahaan

Berdasarkan hasil uji $\mathrm{t}$ di atas, dapat dikatakan bahwa terdapat pengaruh yang signifikan antara jumlah keputusan investasi terhadap nilai perusahaan

2. Pengaruh Variabel kebijakan hutang terhadap nilai perusahaan
Berdasarkan hasil uji t di atas, dapat dikatakan bahwa terdapat tidak pengaruh yang signifikan antara jumlah keputusan investasi terhadap nilai perusahaan.

\section{KoefisienDeterminasi $\left(\mathbf{R}^{2}\right)$}


Koefisien determinasi $\left(\mathrm{R}^{2}\right)$ berfungsi untuk melihat sejauh mana variabel independen mampu menjelaskan variabel dependen. Apabila angka koefisien determinasi semakin mendekati 1, maka pengaruh variabel independen terhadap variabel dependen semakin kuat, yang berarti variabel independen memberikan hampir semua informasi yang dibutuhkan untuk memprediksi variasi variabel dependen.

Uji KoefisienDeterminasi $\left(\mathbf{R}^{2}\right)$

\begin{tabular}{|l|r|r|r|r|r|}
\hline Model & \multicolumn{1}{|c|}{ Rodel Summary } \\
\hline 1 & \multicolumn{1}{|c|}{ R Square } & Adjusted R Square & $\begin{array}{l}\text { Std. Error of the } \\
\text { Estimate }\end{array}$ & Durbin-Watson \\
\hline
\end{tabular}

a. Predictors: (Constant), kebijakan hutang, keputusan investasi

b. Dependent Variable: nilai perusahaan

Disesuaikan digambargan darinilai Adjusted $R$ Square dalah 0.924 yang menunjukkan bahwavariabilitas variable dependen nilai perusahaan yang diukur denganPrice Book Value (PBV) dapat dijelaskan oleh variabilitas variableindependen keputusan investasi yang diukur dengan rasio Price Earnings Ratio dan Debt to Equity Ratio sebesar 0.924 atau 92,4\%. Menurutpedoman interpretasi koefisien korelasi, angka ini termasuk korelasiyang kuat, sedangkan sisanya 0.076 atau $7,6 \%$ dijelaskan oleh variablelainnya yang tidak dimasukkan ke dalam model regresi. Inimenunjukkan bahwa korelasi antara keputusan investasi dan kebijakan hutang adalah korelasi kuat.

\section{PEMBAHASAN HASIL PENELITIAN}

\section{Pengaruh Keputusan Investasi Terhadap Nilai Perusahaan}

Hasil analisis membuktikan bahwa variabel yang keputusan investasi berpengaruh positif terhadap nilai perusahaan.

\section{Pengaruh Kebijakan Hutang Terhadap Nilai Perusahaan}

Hasil analisis membuktikan bahwa variabel yang kebijakan hutang berpengaruh negatif terhadap nilai perusahaan.

\section{SIMPULAN DAN SARAN SIMPULAN}

1. Hipotesis penelitian yang menyatakan bahwa keputusan investasi berpengaruh signifikan terhadap nilai perusahaan diterima. Hal ini terjadi karena perusahaan telekomunikasi dengan signaling theory yang menyatakan bahwa suatu tindakan yang diambilmanajemen perusahaan yang memberi petunjuk (signal) bagi investor tentangbagaimana manajemen memandang proyek perusahaan.

2. Hipotesis penelitian yang menyatakan bahwa kebijakan hutang berpengaruh signifikan terhadap nilai perusahaan ditolak. Hal ini mengindikasi semakin tinggi atau rendah hutang yang dimiliki perusahaan tidak mampu mempengaruhi nilai perusahaan.

\section{SARAN}

Penelitian yang akan datang dapat mencoba menggunakan proksi kinerja keuangan yang lebih kompleks untuk melihat konsistensi hasil penelitian

\section{DAFTAR PUSTAKA}

Agus Harjito dan Martono. 2010. Manajemen keuangan. Yogyakarta: ekonisia

Ang, Robert. 1997. Buku Pintar Pasar Modal Indonesia, Jakarta, Mediasoft Indonesia.

Brigham, E. F. dan J. F. Houston. 2011. Dasar Dasar Manajemen Keuangan. Salemba Empat. Jakarta.

Candra pami hemastuti dan suwardi bambang hermanto. 2014. Pengaruh Profitabilitas, Kebijakan Dividen, Kebijakan Hutang, Keputusan Investasi dan Kepemilikan Insider Terhadap Nilai Perusahaan. Jurnal Ilmu \& Riset Akuntansi Vol. 3 No. 4

Dewi yunitasari dan maswar paruh priyadi. 2014. Pengaruh Keputusan Investasi, Pendanaan, Kebijakan Dividen, dan Tingkat Suku Bunga Terhadap Nilai Perusahaan. Jurnal 
Ilmu \& Riset Akuntansi Vol. 3 No. 4

Diana Ajeng Pratiwi dan Nurul Widyawati. 2017. Pengaruh Kepemilikan Manajerial, Ukuran Perusahaan dan Kebijakan Hutang Terhadap Nilai Perusahaan. Jurnal Ilmu dan Riset Manajemen Vol. 6, No. 12

Evrila Lupita Sari dan Andhi Wijayanto. 2015. Pengaruh Keputusan Investasi, Pendanaan, dan Dividen Terhadap Nilai Perusahaan Dengan Risiko Sebagai VariabelMediasi. Management Analysis Journal 4. (http://journal.unnes.ac.id/sju/index.php/ma j)

Fahmi, Irham. 2013. Analisis Laporan Keuangan. Bandung: Alfabeta.

Fendyka Luqman Ilhamsyah dan Hendi Soekotjo. 2017. Pengaruh Kebijakan Dividen, Keputusan Investasi, dan Profitabilitas Terhadap Nilai Perusahaan. Jurnal Ilmu dan Riset Manajemen Vol. 6, No. 2

Gayatri, Ni Luh Putu Rassri dan I Ketut Mustanda. 2013. Pengaruh Struktur Modal, Kebijakan Dividen dan Keputusan Investasi Terhadap Nilai Perusahaan. Jurnal Manajemen dan Kewirausahaan

Ghozali,Imam.2013.Aplikasi Analisis Multivariate dengan Program IBM SPSS 21Update PLS Regresi. Semarang: Badan PenerbitUniversitas Diponegoro.

Gitman, Lawrence J, 2006.Principles of Managerial Finance. USA, Pearson.

Hanafi, Mahmud M. 2010. Manajemen Keuangan. Cetakan ke lima. Yogyakarta: BPFE.

Harmono, 2011.Manajemen Keuangan Berbasis Balance Scorecard Pendekatan Teori, Kasus dan Riset Bisnis (Edisi I). Jakarta: Bumi Aksara.

Hasnawati, Sri. 2005a. "Implikasi Keputusan Investasi, Pendanaan, dan Dividen terhadap Nilai Perusahaan Publik di Bursa Efek Jakarta".Usahawan.No. 09/Th XXXIX. September 2005 : 33-41.

Hermuningsih Sri dan Dewi Kusuma Wardani. 2009. Faktor-Faktor Yang Mempengaruhi Nilai Perusahaan Pada Perusahaan Yang Terdaftar Di Bursa Efek Malaysia dan Bursa Efek Indonesia. Jurnal Siasat Bisnis. Vol. 13.No. 2.Hal. 173-18

Heri Setiyo Cahyono dan Ardiani Ika Sulistyawati.
2016. Keputusan Investasi, Keputusan Pendanaan dan Kebijakan Dividen Sebagai Determinan Nilai Perusahaan. Akuisisi-Vol 12 No. 2

Indahningrum, R.P. dan R. Handayani. 2009. Pengaruh Kepemilikan Manajerial, Kepemilikan Institutional, Deviden, Pertumbuhan Perusahaan, Free Cash Flow,dan Profitabilitas terhadap Kebijakan Hutang Perusahaan. Jurnal Bisnis dan Akuntansi Vol. 11(3): 189-207.

Luh Putu Novita Sartini dan Ida Bagus Anom Purbawangsa. 2014. Pengaruh Keputusan Investasi, Kebijakan Dividen, serta Keputusan Pendanaan terhadap Nilai Perusahaan Manufaktur di Bursa Efek Indonesia. Jurnal Manajemen, Strategi Bisnis dan Kewirausahaan Vol. 8, No. 2.

Mardiyati, U., G. N. Ahmad., dan R. Putri. 2012. Pengaruh Kebijakan Dividen, Kebijakan Hutang, dan Profitabilitas terhadap Nilai Perusahaan yang Terdaftar di Bursa Efek Indonesia. Jurnal Riset Manajemen Sains Indonesia (JRMSI). 3(1): 1- 17.

Mulyadi, 2001.Sistem Akuntansi Edisi Tiga. Jakarta : Salemba Empat

Norma safitri dan aniek wahyuati.2015. Pengaruh Struktur Modal dan Keputusan Investasi Terhadap Profitabilitas dan Nilai Perusahaan.Jurnal Ilmu dan Riset Manajemen Vol. 4, No. 2

Rahmawati, Amalia Dewi, Dkk. 2015.Pengaruh Ukuran Perusahaan, Profitabilitas, Struktur Modal, dan Keputusan Investasi Terhadap Nilai Perusahaan. Jurnal Administrasi Bisnis $\quad(J A B) \mid$ Vol. $23 \quad$ No. 2 (http://administrasibisnis.studentjournal.ub. $\underline{\text { ac.id) }}$

Scott, R.W. 1997. Financial Accounting Theory.Prentice - Hall International, Inc.

Setiyati, I. 2011. Pengaruh Kebijakan hutang, Kebijakan Dividen, dan Profitabilitas terhadap Nilai Perusahaan pada Industri Otomotif yang Go Publik di Bursa Efek Indonesia.Skripsi. Program Studi Akuntansi STIESIA Surabaya

Soliha.E. dan Taswan.2002. Pengaruh Kebijakan Hutang Terhadap Nilai Perusahaan Serta Beberapa Faktor yang Mempengaruhinya.Jurnal Bisnis dan Ekonomi STIE Stikubank. Semarang. 
Sugiyono,2012.MetodePenelitianKuantitatifKualitat if dan $R \& D$.Bandung: Alfabeta 2010. Metode Penelitian Pendidikan Pendekatan Kuantitatif, kualitatif, dan $R \& D$. Bandung: Alfabeta

2009. Metode Penelitian Kuantitatif, Kualitatif dan $R \& D$. Bandung : Alfabeta.

1997. Metodologi Penelitian Administrasi. Yogjakarta: CV Alfabeta

Sukirno, Sadono, 2013. Makro ekonomi: Teori Pengantar. Edisi Ketiga, Jakarta: Penerbit Rajawali Pers.

Sunariyah, 2010.Pengantar Pengetahuan Pasar Modal. Edisi Keenam. Yogyakarta: UPPAMP YKPN.

Tandelilin, Eduardus. 2010. Portofolio dan Investasi Teori dan Aplikasi. Edisi pertama. Yogyakarta : Kanisius

Wahidahwati. 2002. Pengaruh Kepemilikan Manajerial dan Kepemilikan Institusional pada Kebijakan Hutang Perusahaan: Sebuah Perspektif Theory Agency. Jurnal Riset Akuntansi Indonesia Vol. 5 No. 1

Wijaya, L.R.P, Wibawa, A. 2010. Pengaruh Keputusan Investasi, Keputusan Pendanaan, Dan Kebijakan Dividen Terhadap Nilai Perusahaan. Simposium Nasional Akuntansi XIII Purwokerto. 